\title{
Illocutionary Acts on Anies Baswedan's Speech in Mayoral Meeting Cities against Covid-19 Global Summit 2020
}

\author{
Dhani Aprilia Sesanti ${ }^{l}$ \\ Entika Fani Prastikawati ${ }^{2}$ \\ Ajeng Setyorini ${ }^{3}$ \\ ${ }^{1}$ English Education Department, Faculty of Languages and Arts Education, Universitas PGRI Semarang, \\ Indonesia; danisessaa@gmail.com \\ ${ }^{2}$ Corresponding author, English Education Department, Faculty of Languages and Arts Education, Universitas \\ PGRI Semarang, Indonesia; entikafani@ upgris.ac.id \\ ${ }^{3}$ English Education Department, Faculty of Languages and Arts Education, Universitas PGRI Semarang, \\ Indonesia; ajengsetyorini@upgris.ac.id
}

Received: May 2, 2021 Accepted: June 8, 2021 Published: July 24, 2021

\begin{abstract}
This study, the researchers aim at describing illocutionary acts and the most frequently found in Anies Baswedan's speech dealing with Covid-19. The researcher uses a descriptive qualitative method to choose the data. The researchers analyze the data using the pragmatic theory specifically a speech act theory proposed by Searle (1979) Illocutionary acts are divided into 5 typesnamely representative, declarative, directive, commissive, and expressive. Then, the researchers obtained the data from Anies in Global Summit 2020 of Mayoral Meeting Cities against Covid-19 by using the clauses as the unit of analysis. The result shows that there are 102 data found in the video. The dominant number found is representative with the total number $55(53,9 \%)$, then followed by declarative $22(21,6 \%)$, directive $12(11,8 \%)$, expressive $8(7,8 \%)$, and commissive $5(4,9 \%)$. Representative is dominant since the data tend to deliver the message by reporting, stating, describing a phenomenon, Covid-19 as the issue that must be solved. In this case, Anies Baswedan is trying to represent the importance of solving Covid-19 as soon as possible by his choice of words, phrases, and sentences. Finally, it is concluded that this study is in line with the theories and the previous studies dealing with illocutionary act. In contrary, there is a previous study contrast with this study. The finding of this study implies that the use of illocutionary needs to be more investigated to see how this kind of pragmatics represent the language use of the speakers.
\end{abstract}

Keywords: Covid-19; Illocutionary Acts; Speech

To cite this article: Sesanti, D.A., Prastikawati, E. F., \& Setyorini, A. (2021). Illocutionary acts on Anies Baswedan's apeech in mayoral meeting cities against Covid-19 Global Summit 2020. SALEE: Study of Applied Linguistics and English Education, 2(2), 105-118. https://doi.org/10.35961/salee.v2i02.251 


\section{Introduction}

Generally, humans are social creatures who need other human beings in the activities of their everyday life. They make communication to convey ideas, feelings, or desires to others. In the process of communication, it will be declared successfully if the messages can be conveyed and understood by the listener or the interlocutor. According to Buck \& Arthur (2002), communication consists of two forms, there are verbal and nonverbal communication. Verbal communication is the way of communicating messages by using words as an element. Besides, nonverbal communication is the way people deliver messages by using gestures, body movements, eye contact, general appearance, and so forth.

Focusing on verbal communication, one of the common forms used by people to share meanings is through a speech. In pragmatics, there are some topics to discuss in verbal communication including speech acts which are the action which is performed via utterances (Yule, 1996). A speech act is an action that the speaker accomplishes when using language in context (Fromkin et al., 2003). It refers to any intentions embedded in an utterance conveyed, such as informing, persuading, convincing, warning, requesting, commanding, offering, greeting, promising, and so on. The theory was introduced by Oxford philosopher J.L. Austin in 1975 and made by American philosopher J.R. Searle. On the other hand, when communicating with each other, a speaker not only utters speech but also acts. This relates to the strategy or strategy to make the speech partner do or not do something following the contents of the utterance delivered by the speaker. Aitchison (2003) stated that the speech act is the action that is performed in saying. Therefore, there are three aspects of speech acts such as, locutionary act, illocutionary act, and perlocutionary act.

Going specifically to illocutionary act, it has a purpose of saying utterances with certain tones, attitudes, feelings, or emotions (giving something such as to inform with a purpose) such as thanking, forgiving, promising, greeting, mocking, congratulating, welcoming, ordering, commanding, requesting, advising, and so forth. Illocutionary act is an act of doing something either for the speaker or the hearer. According to Leech (1983), the illocutionary act is performing the act of saying something. Moreover, Tutuarima et al. (2018) stated that illocutionary act is the speaker's performed action to intend a meaning by producing an utterance. An illocutionary act can also be called an implied level. It means illocutionary acts can be found in certain force phenomena, such as informing, ordering, warning, or undertaking (Austin, 1962). Then, Wardana et al. (2019) added illocutionary act is an act of doing something with a purpose and a specific function. Generally, the illocutionary act has a definition that it can be meant as the hidden meaning of a word or statement. One general classification system lists five types of general functions performed by speech acts (Yule, 1996). Searle (1976) divided the illocutionary acts into five categories, based on Austin's theory, which consists of declarative, representative, expressive, directive, and commisive.

Based on Kreidler (1998), representative illocutionary acts are related to the facts and the goal is to provide information. It means that this type has occurred or not occurred such as stating, boasting, complaining, and claiming. Further is expressive. It is a form of speech act that states what is felt by the speaker. It is used to express emotion, desirability, or the sender's feeling. The expressive function is used to apologize, to beg, to express glad feelings, to congratulate, and the other expressions. Moreover, directive becomes the third type of illocutionary act. Defined by Yule (1996), directive is the illocutionary act that 
attempts by the speaker to get the hearer to do something. It commonly appears with some performative verbs, such as requesting, demanding, questioning, asking, proposing, advising, suggesting, interrogating, urging, encouraging, inviting, begging, ordering, and so forth. The next type is declarative which means that a kind of illocutionary act that changes the world via people's utterances. Lastly, commisive as a kind of illocutionary act that commits the speaker to some future course of action. In performing this type of illocutionary act, it commonly uses performative verbs such as to ask, order, command, request, beg, plead, pray, entreat, permit, advise, dare, and so forth. Directive illocutionary speech acts can be spoken by anyone when the speakers feels the need to express intent and purpose. The use of directive speech acts can be influenced by an aspect of language use called realm (domain).

Some previous studies related to analysis of illocutionary acts have been well documented. The first related study is by Ediwarman et al. (2020) entitled "Illocutionary Speech Acts, Directive and Implementation of Persuasion Text in Junior High School". Using theory proposed by Searle (1976), the result showed that there were 85 directive illocutionary speech acts which were divided into 15 communicative functions. This study has shown that the use of directive illocutionary acts is intended to present the need to express intent and purpose of the speech (Ediwarman et.al, 2020) The next previous study is written by Rais and Triyono (2019) who believed that the assertive speech acts occurs when the speakers and listeners use language to tell what they know and believe in accordance with the facts. The researchers attempted to examine speech acts as the study of pragmatic on the video Prabowo Vs Jokowi using the theory of illocutionary acts. It was found that there were 83 illocutionary acts found in the video of Prabowo Vs Jokowi - Epic Rap Battles of Presidency. Moreover, the frequent number found was assertive with a total of 41 and the lowest number was commissive with a total number of 1 .

Thirdly, Rahayu et al. (2018) analyzed the main character's utterances in Mirror movie. As the result, they found 55 utterances that contain illocutionary acts. It was classified into five types namely representative with a total number of 4 , directive (37, declarative (0), commisive (2), expressive (12). Then, the frequent type found was directives since the main characters mostly expressed their utterances directly, such as ordering, requesting, asking, and commanding. Moreover, eight factors were affecting the illocutionary acts of the main characters using the context of Hymes' speaking model Rahayu (2018). Those were setting, participants, ends, act, sequence, key, instrumentalities, and genre.

The fourth was conducted by Ramayanti and Marlina (2018). The study concerned with speech acts produced by the main character in the Shrek movie script. It has aimed to describe the types of speech acts are produced by the characters in the animation of a western movie entitled "Tangled". The result showed that there are four illocutionary acts found in the movie. Those are directives, representatives, expressive, and commissives. The study also showed that the dominant speech acts used are directives with a totals percentage of $44 \%$. It indicated that the characters of the movie "Tangled" used directives because some of them wanted the other character doing something.

The last previous study was a study from Anin and Novitasari (2015). In their study, the researchers discussed the use of illocutionary acts in utterances of President Joko Widodo's speech in the first when president inauguration (2014) and secondly was in $9^{\text {th }}$ KTT East Asia, in Nay Pyi Taw, Myanmar (2014). Then, the researchers found out the types and functions of illocutionary acts used in President Joko Widodo's speech. Analyzed using 
illocutionary acts proposed by Searle and Leech, the finding showed that there were five types of illocutionary acts found in the study. Those were assertive, directive, commissive, expressive, and declarative. The type of illocutionary acts found most was assertive. Moreover, the study also found four functions of illocutionary acts, such as competitive, convivial, collaborative, and conflictive. Lastly, the function of illocutionary acts found most in the category was collaborative.

Based on some previous studies done earlier, the researcher takes a different study which is never examined by other researchers with the situation of Anies Baswedan's speech in handling Covid-19. It means that the data is fresh because it was produced in 2020. Then, the theory of illocutionary acts by Searle (1979) is used in this study. The researchers used that theory since the researchers want to know what kind of illocutionary speech act found and to examine what context realized in the video, spoken data, about Covid-19 through the theory proposed by Searle. Based on what has been explained, the main research question is "How are illocutionary acts used in the video of Anies Baswedan's speech in Mayoral Meeting Cities against Covid-19 Global Summit 2020?"

\section{Method}

This research employed descriptive qualitative research since it was to describe the types of illocutionary acts used in Anies Baswedan's speech. According to Creswell (2014), qualitative research is an approach to explore and understand the meaning of individuals or groups ascribe to a social or human issue. The descriptive qualitative design was used in order to capture the description of illocutionary acts used by Anies Baswedan in his speech. All collected data were analyzed in percentage and interpreted descriptively by providing some excerpts from the speech.

\subsection{Unit of Analysis}

The data used was the video of Anies Baswedan's speech in mayoral meeting cities against Covid-19 Global Summit 2020. In conducting this research, the unit of analysis of this study is every clause in utterances of the data containing types of illocutionary act. The researcher downloaded the data from YouTube entitled "02 Jun 2020 Gub Anies Baswedan Mengikuti Mayoral Meeting Cities against COVID-19 GLOBAL SUMMIT 2020". The video had 12 minutes 01 second and was presented in English.

\subsection{Instruments}

In this study, in getting data, the researcher used documentation techniques. Documentation here was a non-human source of information. Last, this study explored the utterances of speech by Anies Baswedan in accordance with Searle's theory.

\subsection{Procedures}

In conducting the study, at first keywords of the video going to be analysed were typed in google. The video was bout speech about Covid-19. When the video was found, it was downloaded. Then, the video was watched to make the transcription then. 


\subsection{Data Analysis}

The data analysis started by reading the transcription of the speech. During the reading, the writers focused only on identifying the utterances produced by Anis Baswedan which represent illocutionary acts. When all of the utterances were all identified, those were classified based on the types of the illocutionary acts.

\section{Finding and Discussion}

The data findings are related to the kinds of Anies Baswedan's speech in mayoral meeting cities against Covid-19 Global Summit 2020. The data is classified into the types of illocutionary acts by following the categories of illocutionary acts comprising of representatives, directives, commissive, declarative, and expressive. The data are realized in the utterances produced by Anies Baswedan in spoken data. the findings of those that the researcher found in the video of Anies Baswedan's speech in mayoral meeting cities against Covid-19 Global Summit 2020 are distributed as the table below:

Table 1. Realization of illocutionary acts in the video of Anies Baswedan's speech in mayoral meeting cities against Covid-19 Global Summit 2020

\begin{tabular}{clcc}
\hline NO & Illocutionary Acts & Frequency & Percentage \\
\hline 1 & Representative & 55 & $51,9 \%$ \\
\hline 2 & Directive & 12 & $11,8 \%$ \\
\hline 3 & Commissive & 5 & $6,9 \%$ \\
\hline 4 & Expressive & 8 & $7,8 \%$ \\
\hline 5 & Declarative & 22 & $21,6 \%$ \\
\hline Total & & 102 & $100 \%$ \\
\hline
\end{tabular}

It can be seen that there are 102 data found in the data, video of Anies Baswedan's speech in mayoral meeting cities against Covid-19 Global summit 2020. There are 5 types of illocutionary found in the data. From 102 data, there are representative with 55 data $(51,9 \%)$, declarative with the total number $22(21,6 \%)$, directive $12(11,8 \%)$, expressive $8(7,8 \%)$, and commisive $5(6,9 \%)$. Moreover, the detailed explanation of the data analysis is formulated as follows:

a. Representative

In the video, there are some types found of representative speech act found in the video of Anies Baswedan's speech in mayoral meeting cities against Covid-19 Global summit 2020 as follow.

1. Stating opinion

[1] 9/102: "and I think this is very important for us now to look what's beyond this pandemic in the past six months." 
This utterance is categorized as representative illocutionary act stating opinion. The context here is about the opinion of Anies Baswedan in handling Covid-19 in the past six months ago. The word "I think" in the utterance above deals with Anies Baswedan's thought.

[2] 20/102: "I think all of us experience that,"

This utterance indicates Anies' opinion that several countries in the mayoral meeting experience Covid-19. The word "I think" is dealing with the opinion of Anies Baswedan towards the situation when Covid-19 appeared.

[3] 41/102: "so now I think it's for all of us to start sharing new values about how we manage our cities in the past."

The context of the utterance is about Anies wants to remain the citizens regarding to the Jakarta in past and how the Jakarta manage in the past. To add, the utterance is classified into representative of stating opinion frorm the word "think".

\section{Describing}

[4] 10/102: "Many of us are struggling to save our fellow citizens,"

This utterance can be classified as a representative illocutionary act in the type of describing something. The context here is about the circumstances that are faced by citizens in experiencing Covid-19. The word "struggling" can be defined as the description of the situation at that time until now.

\section{Reporting}

[5] 40/102: "But also our populations is experiencing transformations with that we never expected a few months ago"

It can be seen from the utterance above that the context is about Jakarta citizens experiencing the changes of the situation before Covid-19 and right now. Then, this utterance identifies reporting. It can be seen from the word "our populations is experiencing" refers to true information dealing with Covid-19. Further, the utterance represents unexpected action of people in measuring the damage of Covid-19, so the people are surprised with the rapid movement of Covid-19 in Jakarta.

\section{Stating a fact}

[6] 33/102: "and people started to realize"

The context of the utterance above is about the realization of the people regarding the effect of Covid-19, such as economic crisis, health crisis, and social crisis. Besides, the utterance indicates stating a fact. It means that the pandemic had occurred a few months ago and it is announced as a deadly disease by WHO. From the word "started", it concludes that people's awareness is less than the other country

[7] 4/102: "but we didn't do it" 
The context here is about the meeting that is actually held six months ago. The utterance above is classified into representative of stating a fact. It can be seen from the word "didn't" that means the conference should be held few months ago due to the pandemic, the conference is postponed by the committee. The word "it" means to the meeting or the conference.

[8] 32/102: "we experience blue sky everyday"

The utterance above has context that it is about the situation of Jakarta before the pollute air appears in that city. The utterance above is categorized as representative of describing. It refers to the condition of the sky. Moreover, the word "we" here represents the citizens of Jakarta before and after the pollute air appears.

[9] 38/102: "those are issues,"

The context of the utterance above is about the crisis that Jakarta's facing up dealing with Covid-19 damage. Then, it is classified as representative of stating a fact. It can be seen that the word "those" is representation of three kinds of crisis in Jakarta. Those are economic, social, and health crisis that can be serious problem in Jakarta during the pandemic.

[10] 44/102: "we build public transport,"

The context of the utterance above is about the action that Anies Baswedan takes to develop the public transportation and public services. It is classified as representative of stating a fact. The word "we build" refers to the process of the development in Jakarta from the aspects of beneficial facilities for the citizens.

\section{b. Directive}

According to Searle (1979), directive deals with something that needs to be done by listeners based on the need of the speaker. The performative verbs raise are command, request, ask, beg, pray, treat, invite, and so on. In this study, the researcher has found some examples of a directive of the illocutionary act. The analysis explains as follows.

\section{Permitting}

[11] 6/102: "allow me at this moment to share a little bit of our"

The utterance above has a context that it talks about the permission of Anies Baswedan in telling the story about Jakarta during Covid-19 appears. Then, the utterance indicates directive illocutionary act of permitting. It can be seen from the word "allow me" that Anies tries to asking permission towards all participants. At that time, Anies tends to tell the participants about the story in his leading period in overcoming Covid-19.

\section{Begging}

[12] 12/102: "but, allow me in this opportunity to serve some thoughts regarding how to we move forward Jakarta starting this weekend." 
The context of the utterance above is about Anies's action in begging the permission of all the participants at that meeting to have a speech. The utterance is also identified as begging. It can be from the word "allow me" is a kind of begging action when someone's want to do something either speak up or written down. Moreover, the utterance shows the way Jakarta avoiding the increase of Covid-19's victims.

\section{Encouraging}

\section{[13] 39/102: "that we need to tackle"}

The context of the utterance above is about the way how Anies Baswedan stops the pandemic with his own way. The utterance above is categorized as directive illocutionary act of encouraging. It can be seen from the word "we need" deals with persuasive statement that is produced by Anies to encourage the citizen to take off the pandemic in order to make it smaller. The thing that Anies would like to take off is the crisis that appears in Jakarta, such as social, health, economic crisis.

\section{Suggesting}

[14] 58/102: "we need to start seeing this as an opportunity to transform we live how we live the city"

It can be seen from the utterance above, the context is about the way Jakarta seek and observe the PSBB as the transformation of Jakarta people life. The word "this" refers to PSBB. Then, the utterance indicates suggesting. It can be seen from the word "need to start" that Anies Baswedan suggests the citizens adopt the situation when PBB is applied in Jakarta.

\section{Commanding}

[15] 64/102: "so, the approach that we need to undertake is somewhat different."

The utterance above has a context that explains Anies Baswedan's hope to Jakarta people that they can solve this in a different way. The utterance is classified as commanding or ordering in directive illocutionary acts. It can be seen from the word "that we need to undertake" is an act of ordering people to do something mutual for a lot of people. The thing that should be undertaken is the crisis city. It deals with economic, health, social, and educational crisis.

[16] 96/102: "and we need to look forward the futures where digital-oriented development may be the way to the future micro centric development is perhaps the approach in special planning"

It can be seen from the utterance above that the context is about the command of Anies Baswedan towards Jakarta people to find the opportunities in the future, such as making car development, digital-oriented development, and so forth. This utterance can be classified as a directive illocutionary act of commanding or ordering. It can be seen from the word "need to look forward" refers to the command to do something better that can bring a positive 
influence in one day. Moreover, the utterance may be an indication of a plan which is created by the governor to make Jakarta does not leave behind the other country.

6. Inviting

[17] 81/102: "that we invited them to participate to channel"

The context of the utterance above is about Anies Baswedan's invitation which sends to charity organizations to participate in the event. Then, it can be classified as a directive illocutionary act of inviting. It can be seen from the word "invited" can be defined as a performative verb that contains meaning to attract someone to come. The word "them" refers to charity organizations that have the function to supply the people who were infected by Covid-19 with food, health facility, and money.

[18] 82/102: "that would like to contribute,"

The context of the utterance above is about the donors who wants to join the charity organization in supplying the affected people or the victims of Covid-19 to fulfill his/her needs to live. Then, the utterance above indicates directive illocutionary act of inviting. It can be seen from the word "contribute" deals with the invitation for the charity organization to participate in compress the number of affected people by Covid-19.

\section{Asking}

\section{[19] 75/102: "now Jakarta need you,"}

The context of the utterance above is about an action of asking the citizens to go back as the normal it used to be. Then, the utterance above points out directive illocutionary act of asking. It can be seen from the word "Jakarta need" symbolizes the urgent situation that Jakarta surely needs the cooperation from all the citizens in facing the pandemic.

\section{Requesting}

[20] 76/102: "and our message is let's pay back to our city,"

The context of the utterance above is about Jakarta hope that the visitors will be back to have usual activities in refill the government's profit, such as working, selling and buying in market, opening the tourist destination, and so on. Then, the utterance above classifies directive illocutionary act of requesting. It can be seen from the word "let's" refers to an action that tries to be friendly with the others and has a purpose to request someone to do something.

\section{c. Commissive}

Searle (1979) added that commisive illocutionary act points out the utterance of commitment spoken by the speaker for people's future action. In this study, the researcher has found some examples of commisive of illocutionary act. The analysis explains as follows.

\section{Promising}

[21] 11/102: "to make sure they become they are back to our life again and new normal" 
The utterance above has a context that discussed Anies's pledge to the citizens that Jakarta will be back as suitable as the normal Jakarta they know. Then, the utterance is indicated as commissive illocutionary acts of promising. It can be seen from the word "make sure" implicitly contains a promise that is stated by Anies Baswedan. Moreover, the utterance is pointed out to citizens of Jakarta who are now living outside Jakarta due to the significant problem of Covid-19.

[22] 13/102: "we will start easing up our life skills social distancing measures"

The utterance above has a context about the introduction of social distancing measures that is called PSBB to the citizens to make them easy to adopt this rule and the sequences when it is applied. Then, the utterance is identified as commissive illocutionary act of promising. It can be seen from the word "will start" is dealing with future action that is delivered by someone to the hearer about the plan.

[23] 91/102: "after we completed our approach in next week we would like to make sure that the solidarity were building in the past two-three months is something that we can live under to the future "

The context of the utterance above is about Anies Baswedan's hope that the existence of PSBB can build solidarity in Jakarta. Then, the utterance is classified as commissive illocutionary act of promising. It can be seen from the word "would like to make sure" that it can be categorized as an action to convince someone to trust the speaker. Moreover, social distancing measure (PSBB) is not only implemented now, but it also can be implemented in the future to build the solidarity of citizens when the disaster appears.

\section{Ordering}

[24] 96/102: "and we need to move from simply providing basic services to our citizens"

The utterance above has a context about the requirement of movement in developing the supply from the basic into the developed supply in Jakarta. The utterance is categorized as commissive illocutionary acts of ordering. It can be seen from the word "need to move" that it is a verb of doing something to change the recent into the better one. Here, people know that the governor will change the standard of services into a satisfying standard.

\section{[25] 97/102: "we need to move into resilient turban surfaces"}

The utterance above has a context about the changes surfaces from basic to the resilient to avoid the pandemic becomes lager by giving the victims sustainable shelter. The utterance above indicates commisive illocutionary act of ordering. It can be seen from the word "need to move" refers to the order of Anies Baswedan towards the authority to move the affected people in a sustainable shelter which is resilient.

\section{d. Expressive}

Based Searle's statement (1979), expressive illocutionary act consists of expression of psychological that reflects the speaker's condition of his utterances. It means that the utterances found indicates someone's feeling that is realized in the word thanking, greeting, 
welcoming, comparing, amazed, and so forth. Here the paragraph explanations of the findings of expressive illocutionary act.

\section{Thanking}

\section{[26] 1/102: "Thank you,"}

The context of the utterance above is about Anies Baswedan's expression when he got his turn to speak up in front of the other governors around the world. It is classified as expressive illocutionary acts of thanking. Then, the word "thank you" is categorized as a thanking word that is usually expressed when someone feels respected.

\section{Gratitude}

[27] 2/102: "first of all allow me to express my appreciations, for the invite to join this important gathering of leaders across the globe."

The utterance above has a context about Anies Baswedan's gratitude because he was invited to the committee to attend the mayor's meeting. The utterance above is categorized into expressive illocutionary act of gratitude. It can be seen from the word "express my appreciation" that it is kind of form in grating towards something special to ourselves.

\section{Greeting}

[28] 3/102: "Especially, my appreciation to mayor Park, a very good friend of ours"

The utterance is categorized as expressive illocutionary acts of greeting. Then, the context of the utterance is about Anies Baswedan's respect for Mayor Park who becomes the chief of the meeting at that time. It can be seen from the word "my appreciation". Then, the utterance refers to Anies Baswedan's honor in greeting Mayor Park and the participants there before Anies started to speak up about the case.

\section{Welcoming}

[29] 77/102: "let's give back where we have been given to you from our sea."

The utterance above is classified as an expressive illocutionary act of welcoming. Then, the context is about Anies Baswedan's act in getting the citizen and the visitor back to Jakarta by welcoming them with an invitation. It can be seen in the word "let's give back" that Anies hopes that by saying that utterance, he can welcome everyone back to Jakarta.

\section{e. Declarative}

Searle, as cited in Nirmala (2017), Speech acts that indicate the success implementation of the speech will result in a match between the contents of the proposition and reality that is called as declarative. It means that the statement describing changes in a situation. Then, in the video, there are some types found of declarative speech acts found in the video of Anies Baswedan's speech in mayoral meeting cities against Covid-19 Global summit 2020. 
[30] 18/102: "Number one we have health crisis"

The utterance above is classified as a declarative illocutionary act of information. The context is about the order issue that Jakarta is facing on and is delivered by Anies Baswedan. It can be seen from the word "number one" that it refers to the first point of information about the effect of the significant problem, Covid-19. Further, since people have known it is a deadly virus that comes out recently and it makes them suffer.

[31] 19/102: "number two, we have an economic crisis"

It can be seen that the utterance above indicates the declarative illocutionary act of information. Then, the context is about the order problem that makes the citizens suffer due to the damage of the pandemic. It can be seen from the word "number two" which refers to the information of the damage caused by Covid-19 which is experienced by the citizens. In addition, the damage itself is the economic crisis caused by the application of social distance measure or called PSBB.

\section{[32] 30/102: "pollute air pollutions is one of our challenges,"}

The context of the utterance above is about the main problem that Jakarta has before the Covid-19 appears in that city. Then, the utterance is categorized as declarative illocutionary act of information. It can be seen from the word "is one of our challenges" that the pollute air has been existed for a long time ago and it is still to be a big problem even though there were three periods of governors.

\section{[33] 84/102: "the number of donors have increased more than 220 percent"}

The utterance above is classified as a declarative illocutionary act of information. The context of it is about the data of the people who donor their wealth, such as food, clothes, and money. It can be seen from the word "have increased more than 220 percent" shows the information about the number of people whose donors increased 2 times than it used to be.

[34] 85/102: "even though the amount of donations is much smaller than when it was 100 percent of donors."

It can be seen that the utterance above is classified as a declarative illocutionary act of information. The context is about the decreasing amount of donors because now Jakarta has an economic crisis. It can be seen from the word "much smaller than when it was" shows that there is a change in the aspect of the number of donors due to the economic crisis. It is one point that the people should know the information of a whole case Covid-19.

[35] 100/102: "and the last point is social distancing measures that is adopted in the large scale need to be paired with social-large social solidarity"

The utterance above has a context about the measurement of social distancing measure or called as PSBB that covers the area, environment, and social life. It can be categorized as a declarative illocutionary act of information. It can be seen from the word "the last point" that shows important information dealing with the adaptation of PSBB measurement. The PSBB 
itself is not only done once but also there are some requirements to achieve the success of PSBB in decreasing the number of Covid-19 victims

After checking and understanding the finding above, it can be seen that there is a result. It shows that the number of frequently found in the data, the video of Anies Baswedan's speech in mayoral meeting cities against Covid-19 Global Summit 2020, is representative with total number $55(51,9 \%)$. It can happen because the data points out the statement showing the action of Anies Baswedan as Governor of Jakarta in giving a speech dealing with the big case, Covid-19.

The finding of this research is in line with the previous study from Ramayanti \& Marlina (2018) which focused on finding the kind of illocutionary act by the main character in the movie entitled "Tangled". According to present study, it also focused on the finding illocutionary act produced by Anies Baswedan in Mayoral Meeting Cities against Covid-19 Global Summit 2020 published on YouTube. While in the previous study, the main character produced representative by giving, stating, and informing. Similarly, Anies produced representative by giving, informing, telling, convincing, so on. Meanwhile, directive type was produced in the previous study, such as commanding, requesting, questioning, inviting, etc. However, Anies also produced the type such as requesting, commanding, asking, and inviting. The main character produced commissive by giving the utterances such as promising and refusing. Moreover, in this present study, Anies employed commissive type by giving the utterances such as ordering and promising. Then, for expressive type was produced in the previous study by giving the utterances such as thanking and disliking. In contrary, in this study Anies also expressed his feeling trough giving the utterances such as thanking, gratitude, welcoming, and greeting. The main character in the previous study and Anies Baswedan in this study have similar intention to produce illocutionary act types.

Meanwhile, this finding is contrast with the previous study from Ediwarman et al. (2020) who only focused on directive type of illocutionary act in his study. This previous study focused on finding the illocutionary act of directive and implementation of persuasion text in Junior High School. Then, the directive type occurred when the participant in that moment having a communication each other. They produced directive type in their text. Meanwhile, in this present study Anies Baswedan used all types of illocutionary act such as declarative, representative, commissive, expressive, and directive which focused on speech Anies Baswedan's speech. However, in the previous study, the researchers focused on persuasion text by applying illocutionary act.

\section{Conclusion}

The result shows that representative was used mostly since most of the utterances point out the action of telling the people about the information by reporting, stating, and describing the situation of Anies Baswedan and Jakarta to the audiences of the meeting. The finding of the study reveals that the use of representative illocutionary act helps the readers and hearers in catching the meaning of the speech delivered by the speaker. In English language teaching context, this study may give a contribution to English foreign language students add their insight on the use of illocutionary acts in their English speech and their English daily communication. A further research is needed by exploring another case of illocutionary acts 
used in a wider, newest, and influential issues and contexts in national and international setting.

\section{References}

Aitchison, J. (2003). Teach yourself: Linguistics. Hodder and Stoughton, Ltd.

Anin, K. L., \& Novitasari, N. F. (2015). The analysis of illocutionary acts in the president Joko Widodo's speech. Journal of IlIocutionary Acts, 6(1), 117-129.

Austin, J. L. (1962). How to do things with words. Clarendon Press.

Buck, R., \& Arthur, V. C. (2002). Verbal and nonverbal communication: distinguishing symbolic, spontaneous, and pseudo-spontaneous nonverbal behavior. Journal of Communication, 15, 522-528.

Creswell, J. W. (2014). Research Design: Qualitative, Quantitative, and Mixed Methods Approaches (4th editio). SAGE.

Ediwarman, Syafrizal, \& Mariyana, T. (2020). Illocutionary speech acts, directive and implementation of persuasion text in junior high school. International Journal of Inovation, Creativity, and Change, 12(6).

Fromkin, V., R, R., \& Nina H. (2003). An Introduction to Language (seventh ed). Thomson.

Kreidler, C. W. (1998). Introducing English Semantics. Routlede.

Leech, G. (1983). Principles of Pragmatics. Longman.

Rahayu, F. N., Arifin, M. B., \& Arisani, S. (2018). Illocutionary act in the main character's utterances in "Mirror Mirror" movie. Ilmu Budaya, 2, 175-187.

Rais, B., \& Triyono, S. (2019). Pragmatic analysis of speech acts on the video of Prabowo vs Jokowi - epic rap battles of precidency. International Journal of Linguistics, Literature, and Translation (IJLLT), 2(3).

Ramayanti, D., \& Marlina, L. (2018). The analysis of types illocutionary acts in “TANGLED” movie. E-Journal of English Language \& Literature, 7(1).

Searle, J. (1979). Expression and meaning: studies in the theory of speech acts. Cambridge University Press.

Searle, J. R. (1976). A Classification of illocutionary Acts. Cambridge University Press.

Tutuarima, Z., Nuraeningsih, N., \& Rusiana, R. (2018). An analysis of speech act used in London Has Fallen movie. Vision: Journal for Language and Foreign Language Learning, 7(2), 122. https://doi.org/10.21580/vjv7i23022

Wardana, M. K., Roy, S., \& Ariska, J. (2019). llocutionary acts in President Rodrigo Duterte's speech. International Journal of Cultural an Arts Studies, 3(1), 40-46.

Yule, G. (1996). Pragmatics. Oxford University Express. 